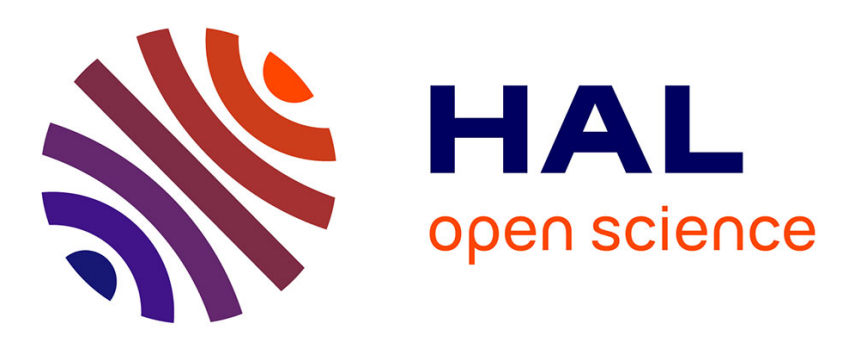

\title{
Hydrogen bonded networks based on hexarhenium(III) chalcocyanide cluster complexes structural and photophysical characterization
}

\author{
Alexandra Ledneva, Sylvie Ferlay, Nikolay G. Naumov, Matteo Mauro, \\ Stéphane Cordier, Nathalie Kyritsakas, Mir Wais Hosseini
}

\section{To cite this version:}

Alexandra Ledneva, Sylvie Ferlay, Nikolay G. Naumov, Matteo Mauro, Stéphane Cordier, et al.. Hydrogen bonded networks based on hexarhenium(III) chalcocyanide cluster complexes structural and photophysical characterization. New Journal of Chemistry, 2018, 42 (14), pp.11888-11895. $10.1039 / \mathrm{c} 8 \mathrm{nj} 02310 \mathrm{~g}$. hal-01861410

HAL Id: hal-01861410

https://hal-univ-rennes1.archives-ouvertes.fr/hal-01861410

Submitted on 14 Sep 2018

HAL is a multi-disciplinary open access archive for the deposit and dissemination of scientific research documents, whether they are published or not. The documents may come from teaching and research institutions in France or abroad, or from public or private research centers.
L'archive ouverte pluridisciplinaire HAL, est destinée au dépôt et à la diffusion de documents scientifiques de niveau recherche, publiés ou non, émanant des établissements d'enseignement et de recherche français ou étrangers, des laboratoires publics ou privés. 


\title{
Hydrogen bonded networks based on hexarhenium(III) chalcocyanide clusters complexes: structural and photophysical characterizations
}

\author{
Alexandra Ledneva, ${ }^{a}$ Sylvie Ferlay, ${ }^{\text {b* }}$ Nikolay G. Naumov, ${ }^{a, c}$ Matteo Mauro, ${ }^{b}$ Stéphane Cordier, ${ }^{d}$ \\ Nathalie Kyritsakas, ${ }^{b}$ Mir Wais Hosseini ${ }^{b^{*}}$
}

\begin{abstract}
Two series of isostructural compounds resulting from the combination of the four-fold hydrogen bond donors bisamidinium cations, namely $1-2 \mathrm{H}^{+}$and $2-2 \mathrm{H}^{+}$, and the anionic chalcocyanide clusters of general formula $\left[\mathrm{Re}_{6} \mathrm{Q}_{8}^{i}(\mathrm{CN})_{6}^{\mathrm{a}}\right]^{4-}$ are presented $\left(\mathrm{Q}=\mathrm{S}\right.$ or $\mathrm{Se}$; where $\mathrm{i}$ and a denote inner and apical position, respectively). $1-2 \mathrm{H}^{+}$is built upon two imidazolium groups linked together by a $-\left(\mathrm{CH}_{2}\right)_{2}-$ alkyl chain. $2-2 \mathrm{H}^{+}$is built upon two hydroxypyrazinium groups linked together via a phenyl group and, in consequence, it exhibits planar geometry. This ionic association leads to either two or three-dimensional hydrogen-bonded networks in the solid state, as confirmed by X-ray crystallographic analysis. The solidstate structures arise from the recognition between the pendant $-\mathrm{C} \equiv \mathrm{N}$ ligands of the cluster cores and the amidinium $\mathrm{H}$ bond donors. The luminescent properties of the compounds are investigated in the solid state by means of steady-state and time-resolved techniques. Results are discussed and compared with those measured for the parental $\mathrm{Cs}_{4}\left[\mathrm{Re}_{6} \mathrm{~S}_{8}^{\mathrm{i}}(\mathrm{CN})_{6}{ }_{6}\right]$ and $\mathrm{Cs}_{4}\left[\mathrm{Re}_{6} \mathrm{Se}_{8}{ }_{8}(\mathrm{CN})_{6}^{\mathrm{a}}\right]$ species. It results that the $\mathrm{H}$-bonded networks displays featureless deep-red emission band centered at $\lambda_{\text {em }}=722$ and $737 \mathrm{~nm}$ and average excited-state lifetimes ranging between 11.5 and $14.8 \mu \mathrm{s}$, in accordance with the triplet nature of the radiative process. These photoluminescence properties are similar to the $\mathrm{Cs}^{+}$homologous and are attributed to the $\left[\operatorname{Re}_{6} Q_{8}^{i}\right]^{2+}$ emitting core.
\end{abstract}

\section{Introduction}

The preparation of molecular compounds with tuneable optical properties is of current interest that is driven by their potential application in various technological areas such as optoelectronics, ${ }^{1,2}$ solar energy conversion, ${ }^{3,4,5,6}$ and sensing, ${ }^{7}$ just to cite some. Nonetheless, design of molecules that possess the desired functions in the solid state is of paramount importance, yet still a challenge in the field of molecular materials. This is due to the fact that molecular optical properties might be largely influenced by the establishment of (extended) intermolecular interactions in the solid states as well as because of excitonic coupling, ${ }^{8,9}$ triplet-triplet

\footnotetext{
a. Nikolaev Institute of Inorganic Chemistry 3 Acad. Lavrentiev pr., 630090 Novosibirsk, Russia

${ }^{b .}$ Molecular Tectonics Laboratory, Université de Strasbourg, CNRS, CMC UMR 7140, F-67000 Strasbourg, France

c. Novosibirsk State University 2 Pirogova str. 630090 Novosibirsk, Russia

${ }^{d .}$ Univ Rennes, CNRS, ISCR (Institut des Sciences Chimiques de Rennes) - UMR 6226, F-35000, France

† Electronic Supplementary Information (ESI) available: Useful bonds and distances for $(1-2 \mathrm{H})_{2}-\left[\operatorname{Re}_{6} \mathrm{Q}_{8}^{\mathrm{i}}(\mathrm{CN})_{6}^{\mathrm{a}}\right](\mathrm{Q}=\mathrm{S}$ or $\mathrm{Se})$ and $(2-2 \mathrm{H})_{2}-\left[\operatorname{Re}_{6} \mathrm{Q}_{8}^{\mathrm{i}}(\mathrm{CN})_{6}^{\mathrm{a}}\right](\mathrm{Q}=\mathrm{S}$ or $\mathrm{Se}), \mathrm{XRPD}$ traces for $(1-2 \mathrm{H})_{2}-\left[\operatorname{Re}_{6} \mathrm{Q}_{8}^{\mathrm{i}}(\mathrm{CN})_{6}^{\mathrm{a}}\right]$ and $(2-2 \mathrm{H})_{2}-\left[\operatorname{Re}_{6} \mathrm{Q}_{8}^{\mathrm{i}}(\mathrm{CN})_{6}^{\mathrm{a}}\right](\mathrm{Q}=\mathrm{S}, \mathrm{Se})$. See DOI: $10.1039 / x 0 x x 00000 x$
}

annihilation ${ }^{10}$ aggregation caused quenching and aggregation induced emission enhancement processes may take place. ${ }^{11}$

To provide structural organization during the formation of solid-state emissive materials, one possibility is the use of noncovalent interactions to direct molecular organization, thus leading fine mastering of the interactions between the different components enabling the enhancement of cooperative effects, like optical properties, for example. Supramolecular chemistry ${ }^{12}$ enables straightforward preparation of interesting functional compounds even in the solid state, where components can be held into the crystals by weak hydrogen bonds, ${ }^{13,14,15}$ being relatively directional, and that can be also strengthen by addition of electrostatic chargecharge interactions (Charge Assisted H-Bond). ${ }^{16,17}$ Hydrogen bonds, also in combination with coordination and/or metalmetal interactions, is a powerful tool to obtain new molecular materials with peculiar optical properties. ${ }^{18}$ Along this line, we demonstrated the formation of a variety of functional hydrogen bonded networks using amidinium-based organic building blocks (Figures 1a-b), combined with mononuclear polycyanometallate complexes as $\mathrm{H}$-bond acceptors, ${ }^{19,20,21}$ some of them presenting luminescent ${ }^{22,23}$ or porous properties. $^{24}$ 
The use of metallic clusters as inorganic building blocks ${ }^{25}$ opens a way for the formation of porous multifunctional molecular materials due to their large size and rigid geometry. Employment of $\left[\mathrm{M}_{6} \mathrm{Q}_{8}^{\mathrm{i}} \mathrm{L}_{6}^{\mathrm{a}}\right]^{\mathrm{q}-}(\mathrm{M}=\mathrm{Mo}, \mathrm{W}$ or Re; $\mathrm{Q}=\mathrm{S}$, Se or Te as inner ligands and $L$ is an apical ligand) has been explored for the formation of new molecular networks and hybrid nanomaterials. ${ }^{26,27,28,29,30,31,32}$ For example, three dimensional bimetallic coordination networks have been reported with $\mu_{3}$ chalcogenido $\left[\operatorname{Re}_{6} \mathrm{Q}_{8}^{\mathrm{i}}(\mathrm{CN})_{6}^{\mathrm{a}}\right]^{4-}(\mathrm{Q}=\mathrm{S}$, Se or Te) compounds combined with transition metal ions. ${ }^{33,34,35,36,37}$ In addition, the rhenium clusters have been evidenced as bright emissive both in solution and in the solid state. ${ }^{38,39,40,41,42,43,44,45,46}$

The use of hydrogen bonds for the development of new compounds based on either hexarhenium or hexamolybdenum clusters has been documented, ${ }^{47,48,49,50}$ leading to a large variety of compounds. In these compounds, $\mathrm{H}$-bonds are relatively weak compared to coulombic interactions and $\mathrm{Re}-$ $\mathrm{CN}$...M coordination bonds. There are scarce examples with structure determining role of $\mathrm{H}$ bonds: compounds based on trans- $\left[\mathrm{Re}_{6} \mathrm{~S}_{8}^{\mathrm{i}}(\mathrm{CN})_{4}^{\mathrm{a}} \mathrm{Cl}_{2}^{\mathrm{a}}\right]^{4-}{ }^{4-}$, (EDT-TTFCONHMe $)_{6}\left[\mathrm{Re}_{6} \mathrm{Se}_{8}(\mathrm{CN})_{6} \mathrm{CH}_{3} \mathrm{CN}\right)_{2}\left(\mathrm{CH}_{2} \mathrm{Cl}_{2}\right)_{2}{ }^{52}$, and (EDT-TTF$\left.\mathrm{CONH}_{2}\right)_{6}\left[\mathrm{Re}_{6} \mathrm{Se}_{8}(\mathrm{CN})_{6}\right]^{53}$ based on $\left[\operatorname{Re}_{6} \mathrm{Q}_{8}^{\mathrm{i}}(\mathrm{CN})_{6}^{\mathrm{a}}\right]^{4-}(\mathrm{Q}=\mathrm{S}$, Se or Te) clusters, $\left(\mathrm{Bu}_{4} \mathrm{~N}\right)_{2} \mathrm{H}\left[\mathrm{Re}_{6} \mathrm{Te}_{8}^{\mathrm{i}}(\mathrm{CN})_{6}^{\mathrm{a}}\right] \cdot 2 \mathrm{H}_{2} \mathrm{O}$, $\left(\mathrm{Ph}_{4} \mathrm{P}\right)_{2}(\mathrm{H})\left[\mathrm{Re}_{6} \mathrm{Se}_{8}^{\mathrm{i}}(\mathrm{CN})_{6}^{\mathrm{a}}\right] \cdot 8 \mathrm{H}_{2} \mathrm{O},{ }^{54}$ or $\mathrm{H}[\mathrm{cis}-$ $\left.\mathrm{Fe}\left(\mathrm{H}_{2} \mathrm{O}\right)_{2}\right]\left[\mathrm{Re}_{6} \mathrm{Se}_{8}^{\mathrm{i}}(\mathrm{CN})_{6}^{\mathrm{a}}\right] \cdot 2 \mathrm{H}_{2} \mathrm{O} .{ }^{55}$

In the attempt to extend our hydrogen-bonding approach towards the formation of new cluster-based extended networks and to explore the optical properties of the resulting supramolecular solid-state materials, we hereafter report on two series of $\mathrm{H}$-bonded networks involving $\left[\operatorname{Re}_{6} \mathrm{Q}_{8}^{\mathrm{i}}(\mathrm{CN})_{6}^{\mathrm{a}}\right]^{4-}(\mathrm{Q}$ $=\mathrm{S}$ or $\mathrm{Se}$ ) anions and amidinium cations as $\mathrm{H}$-bond acceptor adnd four-fold $\mathrm{H}$-bonds donors, respectively. Their chemical structure is displayed in Figure $1 \mathrm{a}-\mathrm{b}$. Besides their different composition, these $1-2 \mathrm{H}^{+}$and $2-2 \mathrm{H}^{+}$cations differ in the degree of rigidity. On one hand, $1-2 \mathrm{H}^{+}$can be depicted as two imidazolium groups linked together by a $-\mathrm{CH}_{2}-\mathrm{CH}_{2}-$ alkyl chain. On the other hand, $2-2 \mathrm{H}^{+}$can be depicted as two hydroxypyrazinium groups linked together via a benzoic group. Consequently, $2-2 \mathrm{H}^{+}$exhibits planar geometry. As shown in Figures $1 a-b$, the average distances between the $\mathrm{N}$ atoms of linked amidinium rings are 3.5 and $7 \AA$ for $1-2 \mathrm{H}^{+}$and $2-2 \mathrm{H}^{+}$, respectively. ${ }^{56,21}$ Similarly to the mononuclear hexacyanometallate $\left[\mathrm{M}(\mathrm{CN})_{6}\right]^{\mathrm{q}-}$ analogues, the $\left[\operatorname{Re}_{6} \mathrm{Q}_{8}^{\mathrm{i}}(\mathrm{CN})_{6}^{\mathrm{a}}\right]^{4-}$ anions present six pendant terminal $-\mathrm{C} \equiv \mathrm{N}$ groups orthogonally disposed at the vertices of the octahedral $\mathrm{Re}_{6}$ cluster (Figure 1c). As already reported in previous crystallographic studies, average distances between $-\mathrm{C} \equiv \mathrm{N}$ groups within cluster are about $7 \AA$ for $-\mathrm{C} \equiv \mathrm{N}$ groups in cis position and $10 \AA$ for the groups in trans position (Figure 1c)..$^{51-55}$ This feature enables the dihapto recognition mode through $\mathrm{H}$ bond between the donors and acceptors.

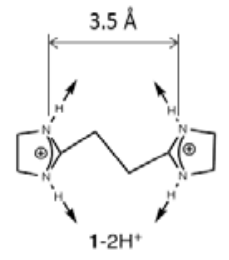

a

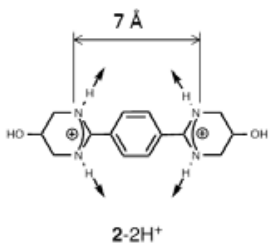

b

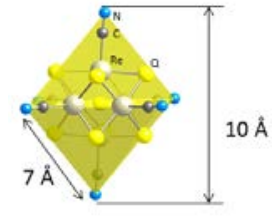

C
Figure 1: Dicationic bisamidinium compounds $1-2 \mathrm{H}^{+}$(a) and $2-2 \mathrm{H}^{+}(\mathrm{a})$, acting as $\mathrm{H}$ bond donors

To gain deeper insights into the solid-state organization of the prepared compounds, structural analysis of the formed hydrogen bonded networks were performed. In addition, detailed luminescence characterization was carried out in the solid state and the findings compared with those of $\mathrm{Cs}_{4}\left[\operatorname{Re}_{6} \mathrm{~S}_{8}^{\mathrm{i}}(\mathrm{CN})_{6}^{\mathrm{a}}\right]$ and $\mathrm{Cs}_{4}\left[\operatorname{Re}_{6} \mathrm{Se}_{8}^{\mathrm{i}}(\mathrm{CN})_{6}^{\mathrm{a}}{ }_{6}\right]$.

\section{Results and discussion}

\section{Structural investigations of the frameworks}

The interaction of the hydrogen bonds donors $1-2 \mathrm{H}^{+}$and 2$2 \mathrm{H}^{+}$with $\left[\mathrm{Re}_{6} \mathrm{~S}_{8}^{\mathrm{i}}(\mathrm{CN})_{6}^{\mathrm{a}}\right]^{4-}$ and $\left[\mathrm{Re}_{6} \mathrm{Se}_{8}^{\mathrm{i}}(\mathrm{CN})_{6}^{\mathrm{a}}{ }_{6}{ }^{4-}\right.$ yielded stable crystals suitable for X-Ray diffraction (see experimental part). The crystallization results from a cationic metathesis that occurs under mild condition by layering a solution of $1-2 \cdot \mathrm{HCl}$ and $2-2 \cdot \mathrm{HCl}$ on a solution of $\mathrm{Cs}_{4}\left[\operatorname{Re}_{6} \mathrm{Q}_{8}^{\mathrm{i}}(\mathrm{CN})_{6}^{\mathrm{a}}\right] \cdot 3 \mathrm{H}_{2} \mathrm{O}(\mathrm{Q}=\mathrm{S}$ and $\mathrm{Se})$. For all compounds in the crystal state, the cations $1-2 \mathrm{H}^{+}$ and $2-2 \mathrm{H}^{+}$present interatomic distances close to those already reported for related species (see Table S1). ${ }^{21,56}$ The cluster anions $\left[\operatorname{Re}_{6} \mathrm{Q}_{8}^{\mathrm{i}}(\mathrm{CN})_{6}^{\mathrm{a}}\right]^{4-}(\mathrm{Q}=\mathrm{S}$ or Se) exhibit also the typical $\mathrm{M}_{6} \mathrm{Q}_{8}^{\mathrm{i}} \mathrm{L}_{6}^{\mathrm{a}}$ architecture, with an almost ideal geometry. The $\mathrm{Re}_{6}$ octahedral clusters are surrounded by eight chalcogen atoms to form a $\mathrm{Q}_{8}$ cube. $^{37}$ Additionally, each rhenium atom is coordinated by a terminal CN group. Geometrical parameters are listed in Table S1 of the Electronic Supplementary Information (ESI). Bonds and angles within the clusters are close to those already reported for other salts with discrete $\left[\operatorname{Re}_{6} \mathrm{Q}_{8}^{\mathrm{i}}(\mathrm{CN})_{6}^{\mathrm{a}}\right]^{4-}$ anions, like for instance $\mathrm{K}_{4}\left[\mathrm{Re}_{6} \mathrm{Se}_{8}^{\mathrm{i}}(\mathrm{CN})_{6}^{\mathrm{a}}{ }_{6}{ }^{57}\right.$ $\mathrm{KCs}_{3}\left[\operatorname{Re}_{6} \mathrm{Se}^{\mathrm{i}}(\mathrm{CN})_{6}^{\mathrm{a}}{ }_{6}{ }^{58}\right.$ or $\left[\mathrm{NMe}_{4}\right]_{4}\left[\operatorname{Re}_{6} \mathrm{Se}_{8}{ }_{8}(\mathrm{CN})_{6}^{\mathrm{a}}\right] \cdot 3.33 \mathrm{H}_{2} \mathrm{O} .{ }^{59}$

The interaction of $\left[\operatorname{Re}_{6} \mathrm{Q}_{8}^{i}(\mathrm{CN})_{6}^{\mathrm{a}}\right]^{4-}(\mathrm{Q}=\mathrm{S}$ or Se) with the flexible $1-2 \mathrm{H}^{+}$cations leads to two crystalline material of formula $\quad\left[\mathrm{C}_{8} \mathrm{H}_{16} \mathrm{~N}_{4}\right]_{2}\left[\operatorname{Re}_{6} \mathrm{Q}_{8}^{\mathrm{i}}(\mathrm{CN})_{6}^{\mathrm{a}}\right], \quad\left\{(1-2 \mathrm{H})_{2}-\left[\operatorname{Re}_{6} \mathrm{Q}_{8}^{\mathrm{i}}(\mathrm{CN})_{6}^{\mathrm{a}}\right]\right\}$, where $Q=S$ or Se (see crystallographic Table 1). Both compounds $(1-2 \mathrm{H})_{2}-\left[\operatorname{Re}_{6} \mathrm{Q}_{8}^{\mathrm{i}}(\mathrm{CN})_{6}^{\mathrm{a}}\right](\mathrm{Q}=\mathrm{S}$ or Se) crystallise in the $P 2_{1} / \mathrm{n}$ space group. They are isomorphous and present the same connectivity pattern. Crystals are exclusively built up from the organic compound $1-2 \mathrm{H}^{+}$and the inorganic anion $\left[\operatorname{Re}_{6} \mathrm{Q}_{8}^{i}(\mathrm{CN})_{6}^{\mathrm{a}}\right]^{4-}(\mathrm{Q}=\mathrm{S}$ or $\mathrm{Se})$ and no solvent molecules were found. Each anion is surrounded by six cations oriented in the three space directions and each of this latter is surrounded by three anions so that the anion:cation ratio is equal to $1: 2$ (Figures 2a-b). The resulting architecture is 3D cubic-like $\mathrm{H}$ 
bonded structure due to the octahedral environment of the clusters. The cations behave as linkers between the clusters, as shown in Figure $2 \mathrm{c}$. The structure of $(1-2 \mathrm{H})_{2}-\left[\operatorname{Re}_{6} \mathrm{Q}_{8}^{\mathrm{i}}(\mathrm{CN})_{6}^{\mathrm{a}}\right]$ is based on two interpenetrated 3D cubic-like $\mathrm{H}$ bonded structure, leading to a compact structure, as shown in Figure $2 d$.

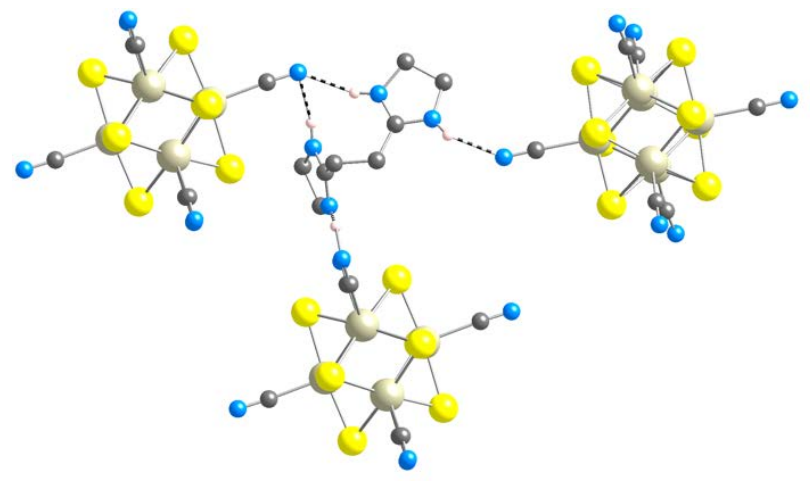

a

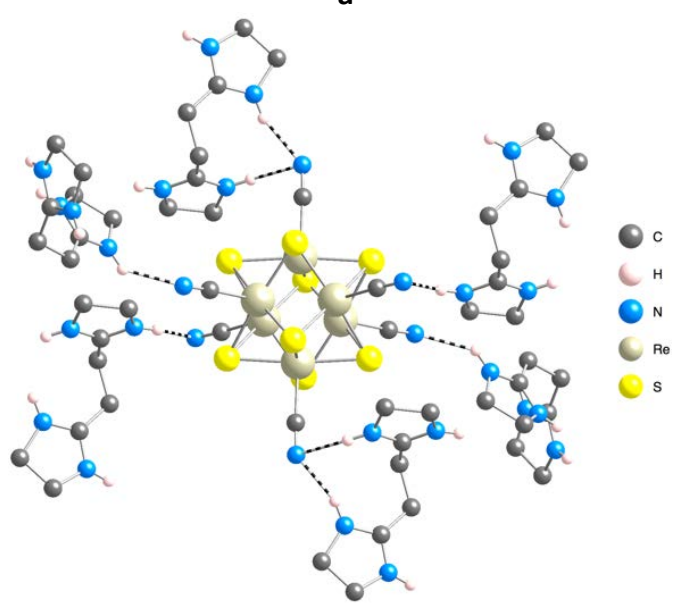

b

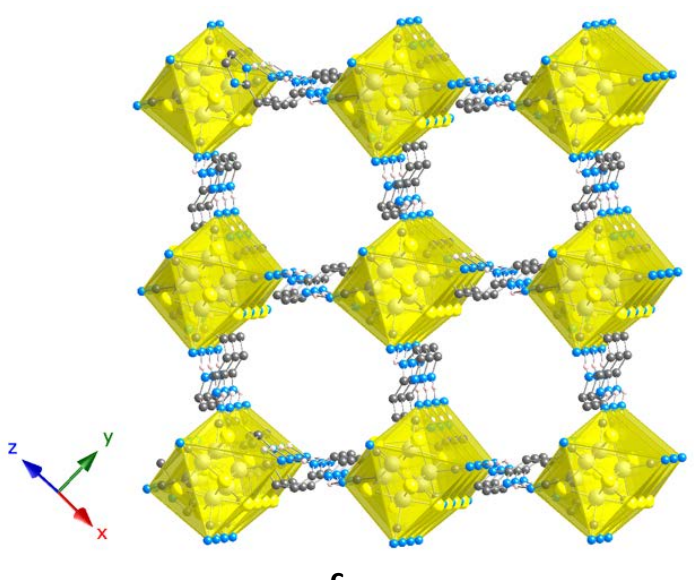

c

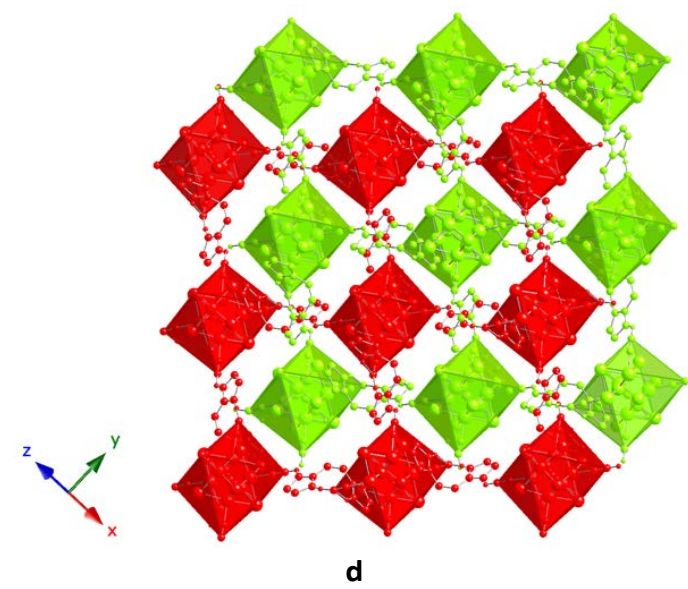

Figure 2: Representations of the crystal structure of $(1-2 \mathrm{H})_{2}-\left[\mathrm{Re}_{6} \mathrm{Q}_{8}^{\mathrm{i}}(\mathrm{CN})_{6}^{\mathrm{a}}\right](\mathrm{Q}=\mathrm{S}$ or $\mathrm{Se}$, and here $Q=S$ is represented). a) environment of the cationic unit, b) environment of the anionic cluster unit, $\mathrm{c}$ ) the three-dimensional framework formed by the recognition of $1-2 \mathrm{H}^{+}$by $\left[\operatorname{Re}_{6} \mathrm{Q}_{8}^{i}(\mathrm{CN})_{6}^{\mathrm{a}}\right]^{4-}$ and $\mathrm{d}$ ) interpenetration of two three dimensional frameworks. For clarity, some of the $\mathrm{H}$ atoms have been omitted.

The clusters and $1-2 \mathrm{H}^{+}$moieties are in contact through the $\mathrm{N}$ donor atoms from amidine moieties of $1-2 \mathrm{H}^{+}$and the $\mathrm{N}$ acceptor atoms from $-\mathrm{C} \equiv \mathrm{N}$. These $-\mathrm{C} \equiv \mathrm{N} \cdots \mathrm{H}-\mathrm{N}$ interactions are characterized by $\mathrm{N} \cdots \mathrm{N}$ distances ranging between $2.844(4)$ and 3.107(5) ^ (see Table S1).

By comparison of the XRPD diagrams of microcrystalline powders of $(1-2 \mathrm{H})_{2}-\left[\operatorname{Re}_{6} \mathrm{~S}_{8}^{\mathrm{i}}(\mathrm{CN})_{6}^{\mathrm{a}}\right]$ and $(1-2 \mathrm{H})_{2}-\left[\operatorname{Re}_{6} \mathrm{Se}_{8}^{\mathrm{i}}(\mathrm{CN})_{6}^{\mathrm{a}}\right]$ with the simulated XRD using structural data obtained by single crystal X-ray diffraction analysis of $(1-2 \mathrm{H})_{2}-\left[\operatorname{Re}_{6} \mathrm{~S}_{8}^{\mathrm{i}}(\mathrm{CN})_{6}^{\mathrm{a}}\right]$ and $(1-2 \mathrm{H})_{2}-\left[\operatorname{Re}_{6} \mathrm{Se}_{8}^{i}(\mathrm{CN})_{6}^{\mathrm{a}}\right]$, it can be concluded these microcrystalline powders do not exhibit traces of impurities (figure S1).

The combination of $\left[\operatorname{Re}_{6} \mathrm{Q}_{8}^{\mathrm{i}}(\mathrm{CN})_{6}^{\mathrm{a}}\right]^{4-}(\mathrm{Q}=\mathrm{S}$ or $\mathrm{Se})$ with the more rigid $2-2 \mathrm{H}^{+}$dication (see experimental part) leads to (2$2 \mathrm{H})_{2}-\left[\operatorname{Re}_{6} \mathrm{Q}_{8}^{\mathrm{i}}(\mathrm{CN})_{6}^{\mathrm{a}}\right]$ (or $\quad\left[\mathrm{C}_{14} \mathrm{H}_{20} \mathrm{~N}_{4} \mathrm{O}_{2}\right]_{2}\left[\operatorname{Re}_{6} \mathrm{Q}_{8}^{\mathrm{i}}(\mathrm{CN})_{6}^{\mathrm{a}}\right]$ ) isostructural crystalline materials $(\mathrm{Q}=\mathrm{S}$ or $\mathrm{Se})$ that crystallize in the triclinic $P$-1 space group (Table 1 ). As found for the two previous described structures, there are no solvent molecules present within the crystal. Each anion is surrounded by six cations and each of this latter is surrounded by three anions, yielding an anion:cation ratio equal to $1: 2$ (Figures $3 a-b$ ), as in the case of $(1-2 \mathrm{H})_{2}-\left[\operatorname{Re}_{6} \mathrm{Q}_{8}^{\mathrm{i}}(\mathrm{CN})_{6}^{\mathrm{a}}\right]$. At first glance, the connectivity between cations and anions can be described as a 1D ladder-like system due to the rigidity of the cationic units, with short $-\mathrm{C} \equiv \mathrm{N} \cdots \mathrm{H}-\mathrm{N}$ interactions between the $\left[\operatorname{Re}_{6} \mathrm{Q}_{8}^{\mathrm{i}}(\mathrm{CN})_{6}^{\mathrm{a}}\right]^{4-} \mathrm{H}$ bond acceptors and $2-2 \mathrm{H}^{+} \mathrm{H}$ bond donors The $\mathrm{N} \cdots \mathrm{N}$ distances range is between $2.875(7)$ and 3.098(8) $\AA$ (see Table 1). The chains are interconnected leading to a $2 \mathrm{D} \mathrm{H}$ bonded system (Figure $3 \mathrm{c}$ ). The parallel packing of these 2D units in the unit cell is depicted in Figure 3d. Additional H-bond reinforcing the formed plans are formed by the free hydroxyl groups attached to the dicationic $2-2 \mathrm{H}^{+}$units through $\mathrm{O} \cdots \mathrm{H}-\mathrm{O}$ bonding with $\mathrm{O} \cdots \mathrm{O}$ distances of $2.817(8) \AA$ A. 


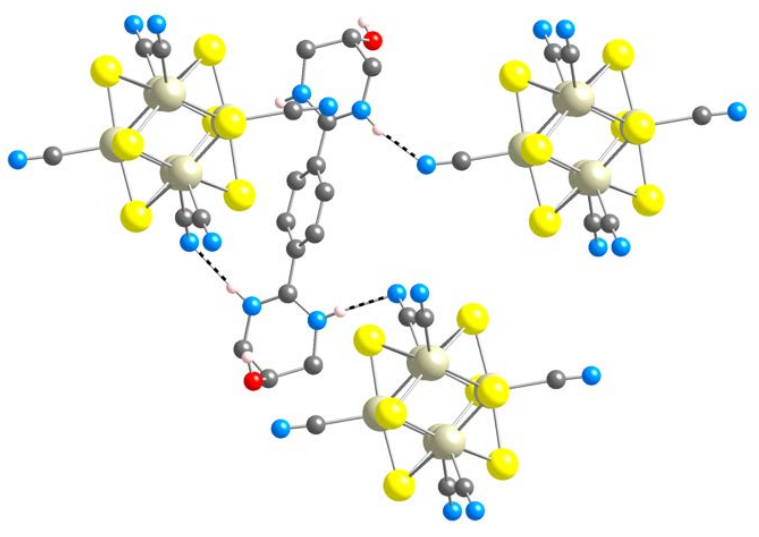

a

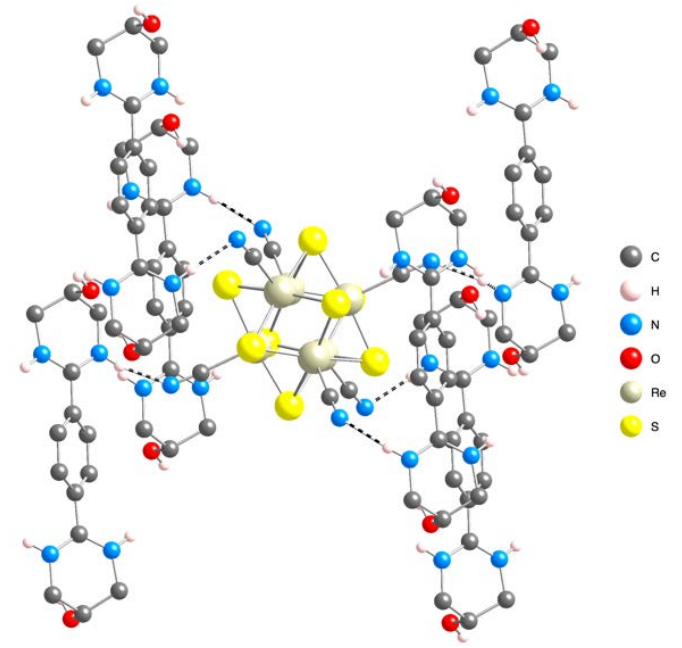

b

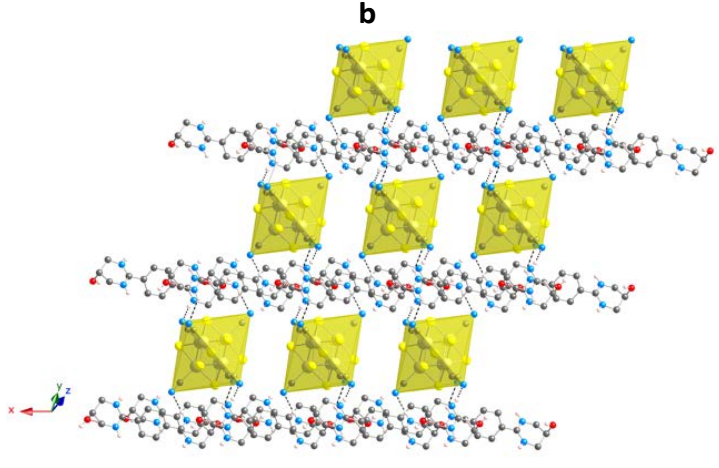

c

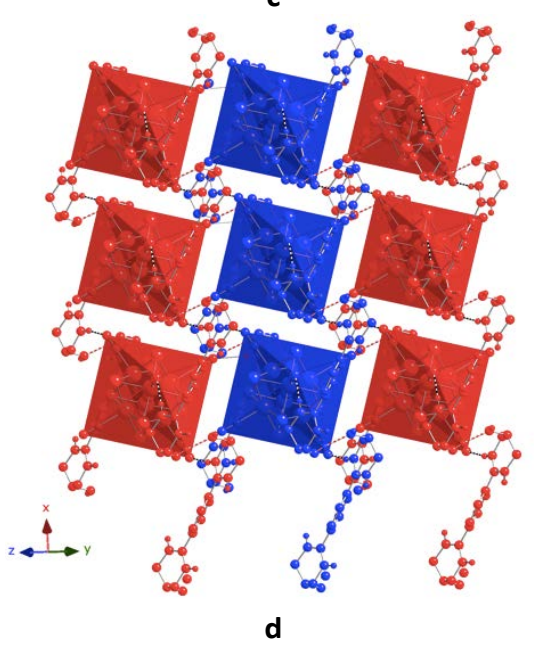

Figure 3: Representation of the structure of $(2-2 \mathrm{H})_{2}-\left[\operatorname{Re}_{6} \mathrm{Q}_{8}^{i}(\mathrm{CN})_{6}^{\mathrm{a}}\right](\mathrm{Q}=\mathrm{S}$ or Se). a) environment of the cationic unit; b) environment of the anionic cluster unit, c) the hydrogen bonded framework leading to a $2 \mathrm{D}$ framework work formed by the recognition of $2-2 \mathrm{H}^{+}$by $\left[\operatorname{Re}_{6} \mathrm{Q}_{8}^{i}(\mathrm{CN})_{6}^{\mathrm{a}}{ }_{6}^{4-}\right.$ and $\mathrm{d}$ ) the packing of the $2 \mathrm{D} \mathrm{H}$-bonded framework. Some of the $\mathrm{H}$ atoms are not presented for clarity.

Both compounds were obtained as pure microcrystalline powders. Indeed, the comparison between XRPD of microcrystalline powders of $(2-2 \mathrm{H})_{2}-\left[\operatorname{Re}_{6} \mathrm{~S}_{8}^{\mathrm{i}}(\mathrm{CN})_{6}^{\mathrm{a}}\right]$ and $(2-2 \mathrm{H})_{2}-$ $\left[\mathrm{Re}_{6} \mathrm{Se}_{8}^{\mathrm{i}}(\mathrm{CN})_{6}^{\mathrm{a}}\right.$ ] with the simulated XRD using structural data obtained by single crystal X-ray diffraction analysis of $(2-2 \mathrm{H})_{2^{-}}$ $\left[\operatorname{Re}_{6} \mathrm{~S}_{8}^{\mathrm{i}}(\mathrm{CN})_{6}^{\mathrm{a}}\right]$ and $(2-2 \mathrm{H})_{2}-\left[\operatorname{Re}_{6} \mathrm{Se}_{8}{ }_{8}(\mathrm{CN})_{6}^{\mathrm{a}}\right]$ (Figure S2) does not evidence the presence of any impurities.

The luminescent properties of these insoluble compounds have been measured in the solid state as neat microcrystalline powders.

Luminescent properties

Hexarhenium(III) chalcogenide clusters containing the $\left[\mathrm{Re}_{6} \mathrm{Q}_{8}^{\mathrm{i}}\right]^{2+}$ core with various terminal ligands $\mathrm{X}$, including halides, phosphines, cyanide and $\mathrm{O}$ - and $\mathrm{N}$ - donor solvent molecules, were found to display long-lived and bright luminescence. This luminescence is relatively unaffected by the physical state of the sample, being fluid solution or solid state, $^{40,60}$ also including ammonium cation ${ }^{61,62}$ and bimetallic complexes with transition and rare earth metals. ${ }^{63,64}$

Detailed photophysical investigation of $\left[\operatorname{Re}_{6} Q_{8}^{i} X_{6}^{a}\right]_{n}$ moieties has been previously reported by several groups and the results rationalized by joint Raman spectroscopy, photophysical techniques and theoretical analysis. ${ }^{38-46}$ The clusters appeared to be characterized by a low-lying absorption bands of ligandto-cluster charge transfer character involving the $\left[\operatorname{Re}_{6} \mathrm{Q}_{8}^{\mathrm{i}} \mathrm{X}_{6}^{\mathrm{a}}\right]^{4-}$

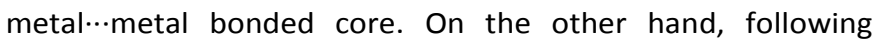
efficient internal conversion and intersystem crossing processes, photoluminescence arises from an excited state with mainly triplet manifold metal-centred character largely localized onto the $\left[\operatorname{Re}_{6} \mathrm{Q}_{8}^{\mathrm{i}}\right]^{2+}$ core. Excited-state lifetimes were found in the order of tens of microseconds, as consequence of the symmetry and spin forbidden nature of the radiative transition and with non-radiative kinetic constant, $k_{\mathrm{nr}}$, which mainly governs the overall emission process. In such derivatives, the nature of the $Q$ ligand largely affects the emission properties. ${ }^{40}$ On the other hand, the axial ligands $L$ affects the emission only in terms of quantum yield and radiative decay by offering vibrational relaxation modes, while emission energies are influenced to a much smaller extent. ${ }^{38-40}$ Noteworthy, the emitting $\left[\operatorname{Re}_{6} \mathrm{Q}_{8}^{i}\right]^{2+}$ core-centred excited state appears to be insulated from the high-energy vibrational levels of the axial moieties when cyano ligands are incorporated into the cluster unit. This finding offers a unique possibility for the construction of extended $\mathrm{H}$-bonded networks via $-\mathrm{C} \equiv \mathrm{N} \cdots \mathrm{H}-\mathrm{N}$ interactions with minor alteration of the photophysical properties of the polynuclear molecular cluster synthon $\left[\operatorname{Re}_{6} Q_{8}^{i}(C N)_{6}^{a}\right]^{4-}$. Thus, the photophysical properties of the four 
solid state networks of formula $(1-2 \mathrm{H})_{2}-\left[\operatorname{Re}_{6} \mathrm{~S}_{8}^{\mathrm{i}}(\mathrm{CN})_{6}^{\mathrm{a}}{ }_{6}\right]$ and (2$2 \mathrm{H})_{2}-\left[\operatorname{Re}_{6} \mathrm{~S}_{8}^{\mathrm{i}}(\mathrm{CN})_{6}^{\mathrm{a}}\right]$ along with the parental $\mathrm{Cs}_{4}\left[\operatorname{Re}_{6} \mathrm{Q}_{8}^{\mathrm{i}}(\mathrm{CN})_{6}^{\mathrm{a}}\right]$ derivatives were investigated as microcrystalline powders by means of steady-state and time-resolved techniques and the results compared with related systems previously reported. The photophysical data are listed in Table 2 and the excitation and emission spectra displayed in Figure 4.

Upon excitation at $360 \mathrm{~nm}$, all the investigated species display broad and featureless emission band falling in the red and near-infrared $(N I R)$ region $\left(\lambda_{\text {em }}=721-737 \mathrm{~nm}\right)$ that can be confidentially attributed to the $\left[\operatorname{Re}_{6} Q_{8}^{i}\right]^{2+}$ scaffold, in accordance with previous reports (see Figure 4). ${ }^{40,40}$ In addition, the nature of the ligand $Q$ seems to do not sizeably affect the emission maximum in the series $\mathrm{Q}=\mathrm{Se}, \mathrm{S}$ as by comparison between $(1-2 \mathrm{H})_{2}-\left[\operatorname{Re}_{6} \mathrm{~S}_{8}^{\mathrm{i}}(\mathrm{CN})_{6}^{\mathrm{a}}\right]$ and $(1-2 \mathrm{H})_{2}-$ $\left[\operatorname{Re}_{6} \mathrm{Se}_{8}^{i}(\mathrm{CN})_{6}^{\mathrm{a}}\right.$ ], being $\lambda_{\text {em }}=723$ and $721 \mathrm{~nm}$, respectively. This is also in agreement with observations made for the $\mathrm{Cs}^{+}$ parental species (see Table 2). Besides, the nature of the cation and, in particular, of the $\mathrm{H}$-donor moiety seems to slightly affect the emission energy, although still to a minor extent. Indeed, going from $1-2 \mathrm{H}^{+}$to $2-2 \mathrm{H}^{+}$a slight bathochromic shift in the order of $170-300 \mathrm{~cm}^{-1}$ is observed for both cluster anions.

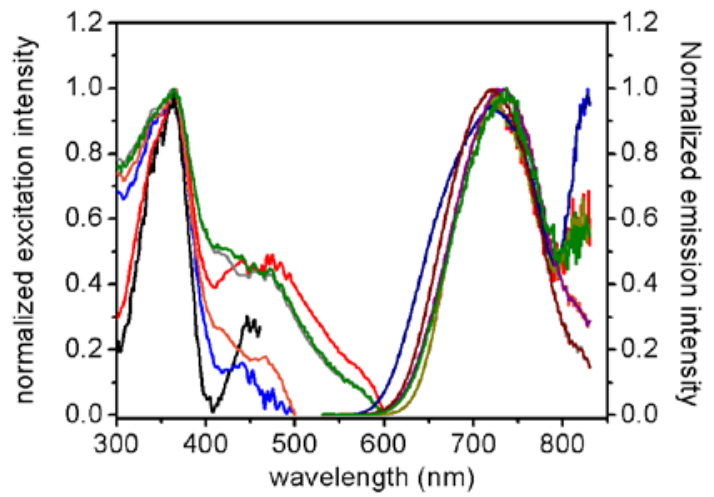

Figure 4: Excitation (left) and emission (right) spectra in the solid state for $(1-2 \mathrm{H})_{2}$ $\left[\operatorname{Re}_{6} \mathrm{Q}_{8}^{\mathrm{i}}(\mathrm{CN})_{6}^{\mathrm{a}}\right],(2-2 \mathrm{H})_{2}-\left[\operatorname{Re}_{6} \mathrm{Q}_{8}^{\mathrm{i}}(\mathrm{CN})_{6}^{\mathrm{a}}\right]$ and the parental compounds $\mathrm{Cs}_{4}\left[\operatorname{Re}_{6} \mathrm{Q}_{8}^{\mathrm{i}}(\mathrm{CN})_{6}^{\mathrm{a}}\right]$ where $Q$ is $S$ or Se. Emission spectra were recorded upon excitation at $\lambda_{\text {exc }}=360 \mathrm{~nm}$ and excitation spectra were recorded monitoring the emission at $\lambda_{\text {em }}=690 \mathrm{~nm}$ for compounds $\mathrm{Cs}_{4}\left[\operatorname{Re}_{6} \mathrm{~S}_{8}^{\mathrm{i}}(\mathrm{CN})_{6}^{\mathrm{a}}\right],(1-2 \mathrm{H})_{2}-\left[\operatorname{Re}_{6} \mathrm{~S}_{8}^{\mathrm{i}}(\mathrm{CN})_{6}^{\mathrm{a}}\right]$ and $(2-2 \mathrm{H})_{2}-\left[\operatorname{Re}_{6} \mathrm{~S}_{8}^{\mathrm{i}}(\mathrm{CN})_{6}^{\mathrm{a}}\right]$, while at $\lambda_{\text {em }}=700 \mathrm{~nm}$ for compound $\mathrm{Cs}_{4}\left[\operatorname{Re}_{6} \mathrm{Se}_{8}{ }_{8}(\mathrm{CN})_{6}^{\mathrm{a}}\right],(1-2 \mathrm{H})_{2}-\left[\operatorname{Re}_{6} \mathrm{Se}_{8}^{\mathrm{i}}(\mathrm{CN})_{6}^{\mathrm{a}}\right],(2-2 \mathrm{H})_{2}$ $\left[\operatorname{Re}_{6} \mathrm{Se}_{8}^{\mathrm{i}}(\mathrm{CN})_{6}^{\mathrm{a}}\right]$. Color code: $\mathrm{Cs}_{4}\left[\operatorname{Re}_{6} \mathrm{~S}_{8}^{\mathrm{i}}(\mathrm{CN})_{6}^{\mathrm{a}}\right]$ black, $\mathrm{Cs}_{4}\left[\operatorname{Re}_{6} \mathrm{Se}_{8}^{\mathrm{i}}(\mathrm{CN})_{6}^{\mathrm{a}}\right]$ red, $(1-2 \mathrm{H})_{2-}$ $\left[\operatorname{Re}_{6} \mathrm{~S}_{8}^{\mathrm{i}}(\mathrm{CN})_{6}^{\mathrm{a}}\right]$ blue, $(2-2 \mathrm{H})_{2}-\left[\operatorname{Re}_{6} \mathrm{~S}_{8}^{\mathrm{i}}(\mathrm{CN})_{6}^{\mathrm{a}}\right]$ orange, $(1-2 \mathrm{H})_{2}-\left[\operatorname{Re}_{6} \mathrm{Se}_{8}^{\mathrm{i}}(\mathrm{CN})_{6}^{\mathrm{a}}\right]$ grey and $(2$ $2 \mathrm{H})_{2}-\left[\operatorname{Re}_{6} \mathrm{Se}_{8}^{i}(\mathrm{CN})_{6}^{\mathrm{a}}\right]$ green trace.

For sake of comparison, excitation spectra were also recorded at $\lambda_{\text {em }}=690 \mathrm{~nm}$ for compounds $\mathrm{Cs}_{4}\left[\operatorname{Re}_{6} \mathrm{~S}_{8}^{\mathrm{i}}(\mathrm{CN})_{6}^{\mathrm{a}}\right],(1-2 \mathrm{H})_{2-}$ $\left[\operatorname{Re}_{6} \mathrm{~S}_{8}^{\mathrm{i}}(\mathrm{CN})_{6}^{\mathrm{a}}\right]$ and $(2-2 \mathrm{H})_{2}-\left[\operatorname{Re}_{6} \mathrm{~S}_{8}^{\mathrm{i}}(\mathrm{CN})_{6}^{\mathrm{a}}\right]$ and $\lambda_{\mathrm{em}}=700 \mathrm{~nm}$ for compounds $\mathrm{Cs}_{4}\left[\operatorname{Re}_{6} \mathrm{Se}_{8}^{\mathrm{i}}(\mathrm{CN})_{6}^{\mathrm{a}}\right],(\mathbf{1}-2 \mathrm{H})_{2}-\left[\operatorname{Re}_{6} \mathrm{Se}_{8}^{\mathrm{i}}(\mathrm{CN})_{6}^{\mathrm{a}}\right]$ and (2$2 \mathrm{H})_{2}-\left[\operatorname{Re}_{6} \mathrm{Se}_{8}^{\mathrm{i}}(\mathrm{CN})_{6}^{\mathrm{a}}\right]$. The spectra features appeared to have broad emission and are in qualitative agreement with already reported electronic absorption spectra for similar species. At higher energy, an excitation maximum at $c a .365 \mathrm{~nm}$ is observed for all the derivatives, independently of $Q$ and cation. Indeed, they clearly shown a modulation of the lowest-lying excitation band upon variation of the nature of $Q$, with a bathochromic shift of the excitation onset going from $Q=$ Se to
$\mathrm{S}$, indicative of the involvement of the chalcogenide atoms into the electronic transition. This lower-energy excitation process can be confidentially ascribed to a transition with ligand-tocluster charge transfer nature involving the $\left[\operatorname{Re}_{6} Q_{8}^{i}\right]^{2+}$ scaffold. Time-resolved photophysical measurements were performed on solid-state samples as well. Overall, the samples show longlived excited state with decay kinetics that were fitted by using multi-exponential decay models and the average lifetimes, $\bar{\tau}$, in the range of 11.5-14.2 $\mu \mathrm{s}$, which are listed in Table 2 (see experimental section for fitting details). Such lifetime values strongly support the triplet nature of the radiative process. As a matter of fact, the $\mathrm{H}$-bonded frameworks displays lifetime similar to the corresponding Cs salts and slightly longer lifetime were recorded for samples involving $1-2 \mathrm{H}^{+}$and $2-2 \mathrm{H}^{+}$ $\mathrm{H}$-bonding donor moiety. Under the hypothesis that the radiative constants $k_{\mathrm{r}}$ are unaffected by the nature of the axial ligand and chalcogenide, as demonstrated elsewhere, ${ }^{40}$ the close lifetime values observed $\mathrm{H}$-bonded species and $\mathrm{Cs}_{4}\left[\operatorname{Re}_{6} \mathrm{Q}_{8}^{\mathrm{i}}(\mathrm{CN})_{6}^{\mathrm{a}}{ }_{6}\right]$ counterparts suggests that the nonradiative rate constant, $k_{\mathrm{nr}}$, remains unaffected in spite of the presence of extended $\mathrm{H}$-bond network in the solid state, which in principle are keen to provide access to nonradiative decay pathways. This finding is in line with the previously reported data which show that the $\left[\operatorname{Re}_{6} Q_{8}^{i}\right]^{2+}$ emitting core in not affected by high-energy vibration modes of the $-\mathrm{C} \equiv \mathrm{N}$ axial ligands. ${ }^{40}$

Table 2. Photophysical data recorded in the solid state for the species $\mathrm{Cs}_{4}\left[\operatorname{Re}_{6} \mathrm{Q}_{8}^{\mathrm{i}}(\mathrm{CN})_{6}^{\mathrm{a}}\right]$ and $\mathrm{H}$-bonded networks $(1-2 \mathrm{H})_{2}-\left[\operatorname{Re}_{6} \mathrm{Q}_{8}^{\mathrm{i}}(\mathrm{CN})_{6}^{\mathrm{a}}\right]$ and $(2-2 \mathrm{H})_{2}-\left[\operatorname{Re}_{6} \mathrm{Q}_{8}^{\mathrm{i}}(\mathrm{CN})_{6}^{\mathrm{a}}\right]$, where $\mathrm{Q}=\mathrm{Se}$ and $\mathrm{S}$.

\begin{tabular}{|c|c|c|c|}
\hline sample & $\begin{array}{c}\lambda_{\mathrm{exc}} \max \\
{[\mathrm{nm}]^{a}}\end{array}$ & $\underset{b}{\lambda_{\text {em }}[\mathrm{nm}]}$ & $\begin{array}{c}\text { Average } \\
\text { lifetime }{ }_{\tau}^{c}[\mu s]\end{array}$ \\
\hline $\mathrm{CS}_{4}\left[\operatorname{Re}_{6} \mathrm{~S}_{8}^{\mathrm{i}}(\mathrm{CN})_{6}^{\mathrm{a}}\right]$ & $364,447 s h$ & 722 & 11.54 \\
\hline $\mathrm{Cs}_{4}\left[\operatorname{Re}_{6} \mathrm{Se}_{8}^{\mathrm{i}}(\mathrm{CN})_{6}^{\mathrm{a}}\right]$ & $365,477 s h$ & 724 & 12.60 \\
\hline$(1-2 \mathrm{H})_{2}-\left[\operatorname{Re}_{6} \mathrm{~S}_{8}^{\mathrm{i}}(\mathrm{CN})_{6}^{\mathrm{a}}\right]$ & $365,442 s h$ & 723 & 13.98 \\
\hline$(2-2 \mathrm{H})_{2}-\left[\operatorname{Re}_{6} \mathrm{~S}_{8}^{\mathrm{i}}(\mathrm{CN})_{6}^{\mathrm{a}}\right]$ & $365,466 s h$ & 732 & 12.35 \\
\hline$(1-2 \mathrm{H})_{2}-\left[\operatorname{Re}_{6} \mathrm{Se}_{8}^{\mathrm{i}}(\mathrm{CN})_{6}^{\mathrm{a}}\right]$ & $365,475 s h$ & 721 & 14.15 \\
\hline$(2-2 \mathrm{H})_{2}-\left[\operatorname{Re}_{6} \mathrm{Se}_{8}^{\mathrm{i}}(\mathrm{CN})_{6}^{\mathrm{a}}\right]$ & $365,473 s h$ & 737 & 13.76 \\
\hline
\end{tabular}

a Emission of the sample was monitored at $\lambda$ em $=690 \mathrm{~nm}$; b Samples were excited at $\lambda$ exc $=360 \mathrm{~nm}$; c Samples were excited at $\lambda$ exc $=370 \mathrm{~nm}$; "sh" denotes a shoulder.

\section{Conclusions}

Through this study, we demonstrated that it was possible to reproducibly obtain two series of hydrogen bonded compounds, through the recognition of the amidinium $\mathrm{H}$ donor atoms with the cyano appended of the $\left[\operatorname{Re}_{6} Q_{8}^{i}(C N)_{6}^{a}\right]^{4-}$ $(\mathrm{Q}=\mathrm{S}$ or $\mathrm{Se})$ cluster building blocks. Two series of isomorphous 
and stable compounds are here reported displaying either 2D or 3D $\mathrm{H}$-bonded networks depending on the rigidity of the employed four-fold $\mathrm{H}$-bond donors.

The luminescent properties of all the $\mathrm{H}$-bonded networks have been investigated as solid-state microcrystalline powders and the findings compared to the reported parental derivatives. Upon photo-excitation, the investigated species display broad and featureless luminescence in the deep-red/NIR region arising from long-lived excited state with lifetimes in the few microseconds regime. This emission is confidentially attributed to the $\left[\operatorname{Re}_{6} Q_{8}^{i}\right]^{2+}$ scaffold with the nature of the chalcogenide atom that affects emission maximum to a minor extent. This is fully in accordance with the results obtained from other materials with isolated $\left[\operatorname{Re}_{6} Q_{8}^{i}(C N)_{6}^{a}\right]^{4-}(Q=S$ or $\mathrm{Se})$ cluster building blocks.

\section{Experimental}

\section{Characterization}

FT-IR spectra were recorded on a Perkin Elmer ATR spectrometer.

Elemental analyses were performed by the Service de Microanalyses de la Fédération de Recherche Chimie of the University de Strasbourg.

\section{Photophysical characterization}

Steady-state emission spectra on solid-state powder in a quartz-tube were recorded at room temperature on a HORIBA Jobin-Yvon IBH FL-322 Fluorolog 3 spectrometer equipped with a $450 \mathrm{~W}$ xenon arc lamp as the excitation source, doublegrating excitation and emission monochromators $(2.1 \mathrm{~nm} \mathrm{~mm}$ 1 of dispersion; 1200 grooves $\mathrm{mm}-1$ ) and a PPD850 singlephoton-counting as the detector. Emission and excitation spectra were corrected for source intensity (lamp and grating) and emission spectral response (detector and grating) by standard correction curves. Time-resolved measurements were performed using the time-correlated single-photon counting (TCSPC) electronics available on the FL-322. A pulsed NanoLEDs (370 nm; FWHM <1 ns) with repetition rate between $10 \mathrm{kHz}$ and $1 \mathrm{MHz}$ was used to excite the sample. The excitation source was mounted on the sample chamber at $90^{\circ}$ to a double grating emission monochromator $(2.1 \mathrm{~nm} \mathrm{~mm}$ dispersion; 1200 grooves $\mathrm{mm}^{-1}$ ) and collected by a PPD singlephoton- counting detector. The photons collected at the detector are correlated by a time-to-amplitude converter (TAC) to the excitation pulse. Signals were collected using an IBH DataStation Hub photon counting module and data analysis was performed using the commercially available DAS6 software (HORIBA Jobin Yvon IBH).

Fitting methods. The quality of the fit was assessed by minimizing the reduced $\chi^{2}$ function and by visual inspection of the weighted residuals and multi-exponential decay model was used for fitting the experiental decay data In such model, the intensity, namely $\mathrm{I}(t)$, has been assumed to decay as the sum of individual single exponential decays (Eq. 1): eq. 1

where $\tau_{\mathrm{i}}$ are the decay times and $\alpha_{\mathrm{i}}$ are the amplitude of the component at $t=0$. In the table, average lifetime, expressed by the following equation (Eqn. 2) as been provided for each sample on the basis of a multi-exponential decay, where the percentages of the pre-exponential factors, $\alpha_{i}$, are used upon normalization.

eq. 1

\section{Crystallography}

Data were collected at $173(2) \mathrm{K}$ on a Bruker APEX8 CCD Diffractometer equipped with an Oxford Cryosystem liquid N2 device, using graphite-monochromated Mo-Ka ( $\lambda=0.71073 \AA$ ) radiation. For all structures, diffraction data were corrected for absorption. Structures were solved using SHELXS-97 and refined by full matrix least-squares on $F^{2}$ using SHELXL-97. The hydrogen atoms were introduced at calculated positions and not refined (riding model). ${ }^{65}$ Structures can be obtained free of charge from the Cambridge Crystallographic Data Centre via www.ccdc.cam.ac.uk/datarequest/cif. CCDC: 18130471813050 .

\section{Powder diffraction studies (PXRD)}

Powder diffraction studies (PXRD) diagrams were collected on polycrystalline samples, on a Bruker D8 diffractometer using monochromatic $\mathrm{Cu}-\mathrm{K} \alpha$ radiation with a scanning range between 3.8 and $40^{\circ}$ using a scan step size of $2^{\circ} / \mathrm{mn}$.

\section{Synthesis}

1-2 $2 \mathrm{HCl}^{24,66} \quad 2-2 \mathrm{HCl}^{21,66} \quad \mathrm{Cs}_{4}\left[\mathrm{Re}_{6} \mathrm{~S}^{\mathrm{i}}(\mathrm{CN})_{6}^{\mathrm{a}}\right] \cdot 3 \mathrm{H}_{2} \mathrm{O}$ and $\mathrm{Cs}_{4}\left[\mathrm{Re}_{6} \mathrm{Se}_{8}^{\mathrm{i}}(\mathrm{CN})_{6}^{\mathrm{a}}\right] \cdot 3 \mathrm{H}_{2} \mathrm{O}$ were obtained by recrystallization from concentrated aqueous solution of $\mathrm{Cs}_{3} \mathrm{~K}\left[\mathrm{Re}_{6} \mathrm{~S}_{8}^{\mathrm{i}}(\mathrm{CN})_{6}^{\mathrm{a}}\right]^{\cdot} \cdot 2 \mathrm{H}_{2} \mathrm{O}^{67}$ and $\mathrm{K}_{4}\left[\operatorname{Re}_{6} \mathrm{Se}_{8}^{\mathrm{i}}(\mathrm{CN})_{6}^{\mathrm{a}}\right]^{\cdot} \cdot 3.5 \mathrm{H}_{2} \mathrm{O}^{57}$ with twenty-fold excess of $\mathrm{CsCl}$.

\section{$(1-2 \mathrm{H})_{2}-\left[\operatorname{Re}_{6} \mathrm{~S}_{8}^{\mathrm{i}}(\mathrm{CN})_{6}^{\mathrm{a}}\right]$}

In a thin crystallization tube (length $100 \mathrm{~mm}$, diameter 10 $\mathrm{mm}), 1 \mathrm{~mL}$ of an aqueous solution of $1-2 \mathrm{HCl}(\mathrm{C}=7.5 \mathrm{mM})$ was gently layered on $2 \mathrm{~mL}$ of an aqueous solution of $\mathrm{Cs}_{4}\left[\operatorname{Re}_{6} \mathrm{~S}_{8}^{\mathrm{i}}(\mathrm{CN})_{6}^{\mathrm{a}}\right] \cdot 3 \mathrm{H}_{2} \mathrm{O}(\mathrm{C}=0.5 \mathrm{mM})$. Upon slow diffusion at the room temperature, yellow crystals, suitable for $\mathrm{X}$-ray analysis, were obtained after one week. Formula $\mathrm{C}_{22} \mathrm{H}_{32} \mathrm{~N}_{14} \mathrm{Re}_{6} \mathrm{~S}_{8}$. Anal. Calcd.: C, $14.16 \% ; \mathrm{H}, 1.73 \%$;, $10.51 \%$; Found: C, 14.08\%; H, $1.69 \% ; \mathrm{N}, 10.43 \%$. IR $v(\mathrm{C} \equiv \mathrm{N}): 2115,2130$ $\mathrm{cm}^{-1}$.

\section{$(1-2 \mathrm{H})_{2}-\left[\operatorname{Re}_{6} \mathrm{Se}_{8}^{\mathrm{i}}(\mathrm{CN})_{6}^{\mathrm{a}}\right]$}

In a thin crystallization tube (length $100 \mathrm{~mm}$, diameter 10 $\mathrm{mm}), 1 \mathrm{~mL}$ of an aqueous solution of $1-2 \mathrm{HCl}(\mathrm{C}=7.5 \mathrm{mM})$ was gently layered on $2 \mathrm{~mL}$ of an aqueous solution of $\mathrm{Cs}_{4}\left[\operatorname{Re}_{6} \mathrm{Se}_{8}^{\mathrm{i}}(\mathrm{CN})_{6}^{\mathrm{a}}\right] \cdot 3 \mathrm{H}_{2} \mathrm{O}(\mathrm{C}=0.5 \mathrm{mM})$. Upon slow diffusion at the room temperature, yellow crystals, suitable for $\mathrm{X}$-ray 
analysis, were obtained after one week. Formula $\mathrm{C}_{22} \mathrm{H}_{32} \mathrm{~N}_{14} \mathrm{Re}_{6} \mathrm{Se}_{8}$. Anal. Calcd.: C, $11.78 \% ; \mathrm{H}, 1.44 \% ; \mathrm{N}, 8.74 \%$; Found: C, 11.73\%; H, $1.45 \%$;, $8.76 \%$. IR $v(\mathrm{C} \equiv \mathrm{N}): 2102,2120$ $\mathrm{cm}^{-1}$.

\section{$(2-2 \mathrm{H})_{2}-\left[\operatorname{Re}_{6} S_{8}^{\mathrm{i}}(\mathrm{CN})_{6}^{\mathrm{a}}\right]$}

In a thin crystallization tube (length $100 \mathrm{~mm}$, diameter 10 $\mathrm{mm}), 1 \mathrm{~mL}$ of an aqueous solution of $2-2 \mathrm{HCl}(\mathrm{C}=7.5 \mathrm{mM})$ was gently layered on $2 \mathrm{~mL}$ of an aqueous solution of $\mathrm{Cs}_{4}\left[\operatorname{Re}_{6} \mathrm{~S}_{8}^{\mathrm{i}}(\mathrm{CN})_{6}^{\mathrm{a}}\right] \cdot 3 \mathrm{H}_{2} \mathrm{O}(\mathrm{C}=0.5 \mathrm{mM})$. Upon slow diffusion at the room temperature, yellow crystals, suitable for X-ray analysis, were obtained after one week. Formula $\mathrm{C}_{34} \mathrm{H}_{40} \mathrm{~N}_{14} \mathrm{O}_{4} \mathrm{Re}_{6} \mathrm{~S}_{8}$. Anal. Calcd.: C, 19.61\%; H, 1.93\%; N, 9.41\%; Found: C, 19.58\%; H, $2.01 \%$; N, $9.37 \%$. IR $v(C \equiv N): 2105,2116$, $2127 \mathrm{~cm}^{-1}$.

\section{$(2-2 \mathrm{H})_{2}-\left[\operatorname{Re}_{6} \mathrm{Se}_{8}^{\mathrm{i}}(\mathrm{CN})_{6}^{\mathrm{a}}\right]$}

In a thin crystallization tube (length $100 \mathrm{~mm}$, diameter 10 $\mathrm{mm}), 1 \mathrm{~mL}$ of an aqueous solution of $2-2 \mathrm{HCl}(\mathrm{C}=7.5 \mathrm{mM})$ was gently layered on $2 \mathrm{~mL}$ of an aqueous solution of $\mathrm{Cs}_{4}\left[\operatorname{Re}_{6} \mathrm{Se}_{8}{ }_{8}(\mathrm{CN})_{6}^{\mathrm{a}}\right] \cdot 3 \mathrm{H}_{2} \mathrm{O}(\mathrm{C}=0.5 \mathrm{mM})$. Upon slow diffusion at the room temperature, yellow needle-like crystals, suitable for X-ray analysis, were obtained after one hour. Formula $\mathrm{C}_{34} \mathrm{H}_{40} \mathrm{~N}_{14} \mathrm{O}_{4} \mathrm{Re}_{6} \mathrm{Se}_{8}$. Anal. Calcd.: C, 16.61\%; $\mathrm{H}, 1.64 \% ; \mathrm{N}, 7.97 \%$; Found: C, 16.57\%; H, $1.68 \%$; N, $7.92 \%$. IR $v_{(C=N)}$ : 2088, 2103, $2126 \mathrm{~cm}^{-1}$.

\section{Conflicts of interest}

The authors declare no conflict of interest.

\section{Acknowledgements}

The work was performed in terms of International Associate Laboratory CLUSPOM (2014-2017 N 1144). A. Ledneva thanks program "Mechnikov" supporting mobility of scientists. Financial supports from the University of Strasbourg, the International Centre for Frontier Research in Chemistry (icFRC), Laboratory of excellence LabEx CSC, Strasbourg, the Institut Universitaire de France, the CNRS are acknowledged.

\section{Notes and references}

₹ Footnotes relating to the main text should appear here. These might include comments relevant to but not central to the matter under discussion, limited experimental and spectral data, and crystallographic data.

1 Highly Efficient OLEDs with Phosphorescent Materials, $\mathrm{H}$ Yersin, Ed., Wiley-VCH, Weinheim, Germany, 2008.

2 Photoluminescent Materials and Electroluminescent Devices, N. Armaroli, H. J. Bolink Eds. in Topics in Current Chemistry, Springer, Cham, 2017.

3 A. Hagfeldt, G. Boschloo, L. Sun, L. Kloo and H. Pettersson. Chem. Rev., 2010, 110, 6595-6663.

4 B. E. Hardin, H. J. Snaith and M. D. McGehee, Nat. Photonics, 2012, 6, 162-169.

5 M. Beley and P. C. Gros, Organometallics, 2014, 33, 45904606.

6 G. J. Hedley, A. Ruseckas and I. D. W. Samuel, Chem. Rev. 2017, 117, 796-837.
7 A. Ruggi, F. W. B. van Leeuwen and A. H. Velders Coord. Chem. Rev., 2011, 255, 2542-2554.

8 F. C. Spano Acc. Chem. Res., 2010, 43, 429-439.

9 B. Heyne Photochem. Photobiol. Sci., 2016, 15, 1103-1114.

10 N. C. Giebink, B. W. D'Andrade, M. S. Weaver, P. B. Mackenzie, J. J. Brown, M. E. Thompson and S. R. Forrest J. Appl. Phys., 2008, 103, 044509.

11 J. Mei, N. L. C. Leung, R. T. K. Kwok, J. W. Y. Lam and B. Z. Tang Chem. Rev., 2015, 115, 11718-11940.

12 J.-M. Lehn, Supramolecular Chemistry, Concepts and Perspectives. Weinheim: 1995.

13 M. C. Etter Acc. Chem. Res. 1990, 23, 120-126.

14 G. A. Jeffery An Introduction to Hydrogen Bonding. Oxford University Press: Oxford, 1997.

15 R. Taylor and O. Kennard Acc. Chem. Res. 1984, 17, 320-326.

16 M. D. Ward Chem. Commun. 2005, 5838-5842.

17 M. D. Ward, Structure and Bonding. In Molecular Networks, Hosseini, M. W., Ed.. Springer: 2009.

18 Hydrogen Bonded Supramolecular Materials, Z-T. Li, L-Z. Wu eds., Springer-Verlag Berlin and Heidelberg Gmb H \& Co. K, 2015.

19 S. Ferlay, O. Felix, M. W. Hosseini, J.-M. Planeix and N. Kyritsakas Chem. Commun. 2002, 702-703.

20 S. Ferlay, V. Bulach, O. Félix, M. W. Hosseini, J.-M. Planeix and N. Kyritsakas CrystEngComm 2002, 4, 447-453.

21 P. Dechambenoit, S. Ferlay, M. W. Hosseini and N. Kyritsakas Chem. Commun. 2007, 4626-4628.

22 C. Paraschiv, S. Ferlay, M. W. Hosseini, V. Bulach and J.-M. Planeix Chem. Commun. 2004, 2270-2271

23 P. Dechambenoit, S. Ferlay, B. Donnio, D. Guillon, N. Kyritsakas and M. W. Hosseini Chem. Commun. 2011, 47, 734-736.

24 P. Dechambenoit, S. Ferlay, N. Kyritsakas and M. W. Hosseini J. Am. Chem. Soc. 2008, 130, 17106-17113.

25 Metal clusters in Chemistry. Wiley-VCH: New York, 1999

26 B. K. Roland, C. Carter and Z. P. Zheng J. Am. Chem. Soc. 2002, 124, 6234-6235.

27 B. K. Roland, H. D. Selby, M. D. Carducci and Z. Zheng J. Am. Chem. Soc. 2002, 124, 3222-3223.

28 M. A. Shestopalov, Y. V. Mironov, K. A. Brylev, S. G. Kozlova,. V. E. Fedorov, H. Spies, H.-J. Pietzsch, H. Stephan, G. Geipel and G. Bernhard J. Am. Chem. Soc. 2007, 129, 3714-3721.

29 K. A. Brylev, Y. V. Mironov, S. S. Yarovoi, N. G. Naumov, V. E. Fedorov, S.-J. Kim, N. Kitamura, Y. Kuwahara, K. Yamada, S. Ishizaka and Y. Sasaki Inorg. Chem., 2007, 46, 7414-7422.

30 A. Y. Ledneva, N. G. Naumov, A. V. Virovets, S. Cordier and Y. Molard J. Struct. Chem. 2012, 53, 132-137.

31 S.Cordier, F. Grasset, Y. Molard, M. Amela-Cortes, R. Boukherroub, S. Ravaine, M.Mortier, N. Ohashi, N. Saito and H. Haneda J. Inorg. Organomet. Polymers Mater., 2015, 25, 189-204.

32 Y. Molard Acc. Chem. Res., 2016, 49, 1514-1523.

33 N. G. Naumov, A. V. Virovets, M. N. Sokolov, S. B. Artemkina and V. E. Fedorov Angew. Chem. Int. Ed. 1998, 37, 19431945.

34 M. P. Shores, L. G. Beauvais and J. R. Long J. Am. Chem. Soc. 1999, 121, 775-779.

35 M. P. Shores, L. G. Beauvais, J. R. Long Inorg. Chem. 1999, 38, 1648-1649.

36 N. G. Naumov, A. V. Virovets and V. E. Fedorov J. Struct. Chem. 2000, 41, 499-520.

37 V. E. Fedorov, N. G. Naumov, Y. V. Mironov, A. V. Virovets, S. B. Artemkina, K. A. Brylev, S. S. Yarovoi, O. A. Efremova. and U.-H. Peak J. Struct. Chem. 2002, 43, 669-684. 
38 T. Yoshimura, S. Ishizaka, K. Umakoshi, Y. Sasaki,. H.-B. Kim and N. Kitamura Chem. Lett. 1999, 697-698.

39 T. G. Gray, C. M. Rudzinski, D. G. Nocera and R. H. Holm Inorg. Chem. 1999, 38, 5932-5933.

40 T. G. Gray, C. M. Rudzinski, E. E. Meyer, R. H. Holm and D. G. Nocera J. Am. Chem. Soc. 2003, 125, 4755-4770.

41 T. G. Gray, C. M. Rudzinski, E. E. Meyer and D. G. Nocera J. Phys. Chem. A, 2004, 108, 3238-3243.

42 K. A. Brylev, Y. V. Mironov, S. G. Kozlova, V. E. Fedorov, S.-J. Kim, H.-J. Pietzsch, H. Stephan, A. Ito, S. Ishizaka and N. Kitamura Inorg. Chem. 2009, 48, 2309-2315.

43 T. Yoshimura, C. Suo, K. Tsuge, S. Ishizaka, K. Nozaki, Y. Sasaki, N. Kitamura and A. Shinohara Inorg. Chem. 2010, 49, 531-540.

44 Y. Molard, F. Dorson, K. A. Brylev, M. A. Shestopalov, Y. Le Gal, S. Cordier, Y. V. Mironov, N. Kitamura and C. Perrin Chem. Eur. J. 2010, 16, 5613-5619.

45 T. Yoshimura, S. Ishizaka, T. Kashiwa, A. Ito, E. Sakuda, A. Shinohara and N. Kitamura Inorg. Chem., 2011, 50, 99189920.

46 M. A. Shestopalov, K. E. Zubareva, O. P. Khripko, Y. I. Khripko, A. O. Solovieva, N. V. Kuratieva, Y. V. Mironov, N. Kitamura, V. E. Fedorov and K. A. Brylev Inorg. Chem. 2014, 53, 90069013.

47 N. Prokopuk, C. S. Weinert, D. P. Siska, C. L. Stern and D. F. Shriver Angew. Chem. Int. Ed. 2000, 39, 3312-3315.

48 A. Deluzet, R. Rousseau, C. Guilbaud, I. Granger, K. Boubekeur, P. Batail, E. Canadell, P. Auban-Senzier and D. Jérome Chem. Eur. J. 2002, 8, 3884-3900.

49 H. D. Selby, B. K. Roland and Z. Zheng Acc. Chem. Res. 2003, 36, 933-944.

50 V. Mironov, K. A. Brylev, M. A. Shestopalov, S. S. Yarovoi, V. E. Fedorov, H. Spies, H.-J. Pietzsch, H. Stephan, G. Geipel, G. Bernhard and W. Kraus Inorg. Chim. Acta 2006, 359, 11291134.

51 N. G. Naumov, A. Y. Ledneva, S.-J. Kim and V. E. Fedorov J. Clust. Sci. 2009, 20, 225-239.

52 S. A. Baudron, P. Batail, C. Rovira, E. Canadell and R. Clérac Chem. Commun. 2003, 1820-1821.

53 S. A. Baudron, P. Batail, C. Coulon, R. Clérac, E. Canadell, V. Laukhin, R. Melzi, P. Wzietek, D. Jérome, P. Auban-Senzier and S. Ravy J. Am. Chem. Soc. 2005, 127, 11785-11797.

54 N. G. Naumov, E. V. Ostanina, A. V. Virovets, M. Schmidtman, A. Müller and V. E. Fedorov Russ. Chem. Bull. 2002, 51, 866871.

55 M. V. Bennett, L. G. Beauvais, M. P. Shores and. J. R. Long, J. Am. Chem. Soc. 2001, 123, 8022-8032.

56 G. Brand, M. W. Hosseini, R. Ruppert, A. De Cian, J. Fischer and N. Kyritsakas New J. Chem. 1995, 19, 9-13.

57 N. G. Naumov, A. V. Virovets, N. V. Podberezskaya and V. E. Fedorov J. Struct. Chem. 1997, 38, 857-862.

58 A. Slougui, Y. V. Mironov, A. Perrin and V. E.Fedorov Croat. Chem. Acta 1995, 68, 885-890.

59 Y. V. Mironov, J. A. Cody, T. E. Albrecht-Schmitt and J. A. Ibers J. Am. Chem. Soc. 1997, 119, 493-498.

60 T. Yoshimura, S. Ishizaka, Y. Sasaki, H. B. Kim, N. Kitamura, N. G. Naumov, M. N. Sokolov and V. E. Fedorov Chem. Lett. 1999, 1121-1122.

61 Y. Molard, A. Ledneva, M. Amela-Cortes, V. Cîrcu, N. G. Naumov, C. Mériadec, F. Artzner and S. Cordier Chem. Mater. 2011, 23, 5122-5130.

62 M. Amela-Cortes, S. Cordier, N. G. Naumov, C. Mériadec, F. Artzner and Y. Molard J. Mater. Chem. C 2014, 2, 9813-9823.
63 S. Kim, Y. Kim, J. Lee, W. Shin, M. Lee and S.-J. Kim Inorg. Chim. Acta 2007, 360, 1890-1894.

64 M. S. Tarasenko, A. Y. Ledneva, N. V. Kurat'eva, D. Y. Naumov, S.-J. Kim, V. E. Fedorov and N. G. Naumov Russ. J. Coord. Chem. 2007, 33, 876-885.

65 Sheldrick, , Program for Crystal Structure Solution. Göttingen, Germany: University of Göttingen, 1997.

66 P.Oxley and W. F. Short J. Chem. Soc. 1947, 497-505.

67 N. G. Naumov, S. B. Artemkina, A. V. Virovets and V. E.Fedorov Solid State Sci. 1999, 1, 473-482. 
Table 1: Crystallographic Parameters for $(1-2 \mathrm{H})_{2}-\left[\operatorname{Re}_{6} \mathrm{~S}_{8}^{\mathrm{i}}(\mathrm{CN})_{6}^{\mathrm{a}}\right],(1-2 \mathrm{H})_{2}-\left[\operatorname{Re}_{6} \mathrm{Se}_{8}^{\mathrm{i}}(\mathrm{CN})_{6}^{\mathrm{a}}\right],(2-2 \mathrm{H})_{2}-\left[\operatorname{Re}_{6} \mathrm{~S}_{8}^{\mathrm{i}}(\mathrm{CN})_{6}^{\mathrm{a}}\right]$ and $(2-2 \mathrm{H})_{2}-\left[\operatorname{Re}_{6} \mathrm{Se}_{8}^{\mathrm{i}}(\mathrm{CN})_{6}^{\mathrm{a}}\right]$ recorded at $173 \mathrm{~K}$.

\begin{tabular}{|c|c|c|c|c|}
\hline & $(1-2 \mathrm{H})_{2}-\left[\operatorname{Re}_{6} \mathrm{~S}_{8}^{\mathrm{i}}(\mathrm{CN})_{6}^{\mathrm{a}}\right]$ & $(1-2 \mathrm{H})_{2}-\left[\operatorname{Re}_{6} \mathrm{Se}_{8}^{\mathrm{i}}(\mathrm{CN})_{6}^{\mathrm{a}}\right]$ & $(2-2 \mathrm{H})_{2}-\left[\operatorname{Re}_{6} \mathrm{~S}_{8}^{\mathrm{i}}(\mathrm{CN})_{6}^{\mathrm{a}}\right]$ & $(2-2 \mathrm{H})_{2}-\left[\operatorname{Re}_{6} \mathrm{Se}_{8}^{\mathrm{i}}(\mathrm{CN})_{6}^{\mathrm{a}}\right]$ \\
\hline Chemical formula & $\mathrm{C}_{22} \mathrm{H}_{32} \mathrm{~N}_{14} \mathrm{Re}_{6} \mathrm{~S}_{8}$ & $\mathrm{C}_{22} \mathrm{H}_{32} \mathrm{~N}_{14} \mathrm{Re}_{6} \mathrm{Se}_{8}$ & $\mathrm{C}_{34} \mathrm{H}_{40} \mathrm{~N}_{14} \mathrm{O}_{4} \mathrm{Re}_{6} \mathrm{~S}_{8}$ & $\mathrm{C}_{34} \mathrm{H}_{40} \mathrm{~N}_{14} \mathrm{O}_{4} \mathrm{Re}_{6} \mathrm{Se}_{8}$ \\
\hline Molecular weight, $\mathrm{g} / \mathrm{mol}$ & 1866.29 & 2241.49 & 2082.48 & 2457.68 \\
\hline Crystal system & Monoclinic & Monoclinic & triclinic & triclinic \\
\hline Space group & $P 2_{1} / \mathrm{n}$ & $P 2_{1} / \mathrm{n}$ & $P-1$ & $P-1$ \\
\hline $\mathrm{a}(\AA \cap)$ & $10.7460(3)$ & $10.7572(4)$ & $10.2728(4)$ & $10.7148(6)$ \\
\hline $\mathrm{b}(\AA)$ & $17.8776(6)$ & $18.2885(8)$ & $11.2485(4)$ & $11.3369(5)$ \\
\hline$c(\AA)$ & $11.2185(4)$ & $11.3229(4)$ & $12.1798(5)$ & $12.3039(5)$ \\
\hline$\alpha(\operatorname{deg})$ & 90 & 90 & $104.230(2)^{\circ}$ & $104.098(2)^{\circ}$ \\
\hline$\beta(\operatorname{deg})$ & $116.7330(10)$ & $117.0480(10)$ & $107.332(2)^{\circ}$ & $107.653(2)^{\circ}$ \\
\hline$\gamma(\operatorname{deg})$ & 90 & 90 & $107.185(2)^{\circ}$ & $109.245(2)^{\circ}$ \\
\hline$V\left(\AA^{3}\right)$ & $1924.85(11)$ & $1983.95(13)$ & $1194.45(8)$ & $1242.73(10)$ \\
\hline Z & 2 & 2 & 1 & 1 \\
\hline Colour & orange & orange & yellow & yellow \\
\hline Crystal dim (mm) & $0.060 \times 0.060 \times 0.070$ & $0.070 \times 0.070 \times 0.080$ & $0.040 \times 0.040 \times 0.050$ & $0.060 \times 0.060 \times 0.070$ \\
\hline Dcalc $\left(\mathrm{gcm}^{-3}\right)$ & 3.220 & 3.752 & 2.895 & 3.284 \\
\hline$F(000)$ & 1680 & 1968 & 952 & 1096 \\
\hline$\mu\left(\mathrm{mm}^{-1}\right)$ & 19.264 & 25.608 & 15.545 & 20.463 \\
\hline Wavelength $(\AA ̊)$ & 0.71073 & 0.71073 & 0.71073 & 0.71073 \\
\hline Reflections collected & 144959 & 61065 & 24080 & 8941 \\
\hline Independent reflections & $5223[\mathrm{R}$ (int) $=0.0480]$ & $5521[\mathrm{R}$ (int) = 0.0340] & $6447[\mathrm{R}$ (int) = 0.0439] & $5744[\mathrm{R}$ (int) = 0.0285] \\
\hline R (all data) & $\mathrm{R} 1=0.0151, \mathrm{wR} 2=0.0351$ & $\mathrm{R} 1=0.0169, w R 2=0.0369$ & $\mathrm{R} 1=0.0289, w R 2=0.0600$ & $\mathrm{R} 1=0.0446, w R 2=0.1128$ \\
\hline Rw (all data) & $\mathrm{R} 1=0.0178, \mathrm{wR} 2=0.0363$ & $\mathrm{R} 1=0.0236, \mathrm{wR} 2=0.0391$ & $R 1=0.0363, w R 2=0.0625$ & $\mathrm{R} 1=0.0692, \mathrm{wR} 2=0.1282$ \\
\hline GOF & 1.188 & 1.093 & 1.047 & 1.015 \\
\hline $\begin{array}{l}\text { Largest diff. peak / hole } \\
\qquad\left(\mathrm{e} \AA^{-3}\right)\end{array}$ & 0.559 and -1.429 & 0.880 and -2.146 & 2.166 and -2.629 & 3.745 and -3.267 \\
\hline
\end{tabular}




\section{Graphical abstract}

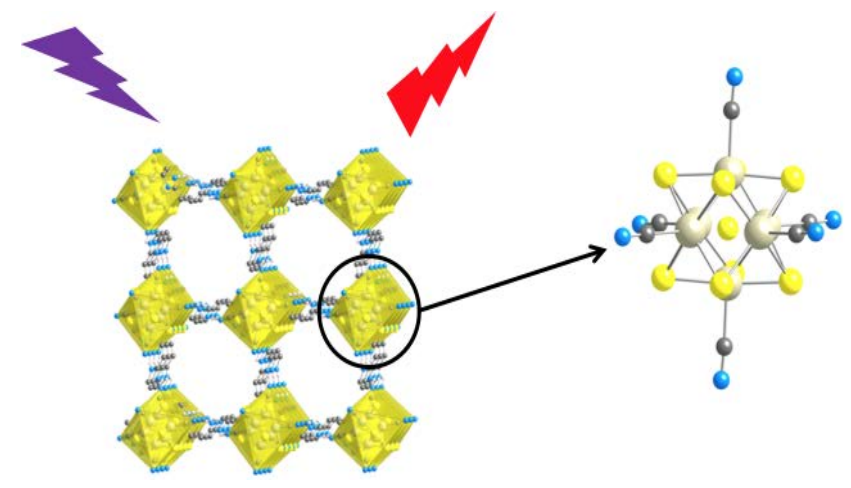

Two series of hydrogen bonded networks based on $\left[\operatorname{Re}_{6} Q_{8}^{i}(C N)_{6}^{a}\right]^{4-}(Q=S$ or $\mathrm{Se})$ anionic clusters and amidinium cations are reported and structurally analyzed. They exhibit red emission bands centered between 722 and $737 \mathrm{~nm}$ upon excitation at 360 or $370 \mathrm{~nm}$ and average lifetimes ranging between 11.5 and $14.8 \mu \mathrm{s}$, in accordance with the triplet nature of the radiative process of the highly emissive $\left[\operatorname{Re}_{6} Q_{8}^{i}\right]^{2+}$ core. 